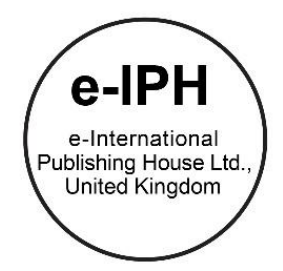

\title{
Exploring the Determinant Factors of Food Related Fatwa Issuances based on 'Urf
}

\author{
Zulaipa Ruzulan, Suhaimi Ab Rahman², Rafeah Saidon'1, Hanifah Musa Fathullah Harun' \\ ${ }^{1}$ Academy of Contemporary Islamic Studies (ACIS), Universiti Teknologi MARA, Shah Alam, Selangor, Malaysia \\ ${ }^{2}$ Faculty of Economics and Management \& Halal Products Research Institute, Universiti Putra Malaysia, Serdang, Selangor, Malaysia \\ faqeh86@gmail.com, suhaimiabrahman@upm.edu.my, rafeahsaidon@hotmail.com, honeyhumairah04@gmail.com \\ Tel of 1 st Author: 013-3564921
}

\begin{abstract}
There are queries on the halal status of food among Muslim consumers due to the accessibility of halal knowledge via mass media, and this needs for the jurists' clarification (fatwa). Thus, this paper seeks to examine the determinant factors of fatwa's decisions on food-related issues based on the approach of 'urf. A qualitative approach which involved document analysis technique was applied from various authoritative sources. Furthermore, content analysis and constant comparative methods were used to analyze the data. This study will assist policymakers in dealing with food-related issues and help the public in identifying the rationale of the fatwa's decisions.
\end{abstract}

Keywords: Fatwa; halal food; istițābah; 'urf

eISSN: 2398-4287 @ 2020. The Authors. Published for AMER ABRA cE-Bs by e-International Publishing House, Ltd., UK. This is an open access article under the CC BYNC-ND license (http://creativecommons. org/licenses/by-nc-nd/4.0). Peer-review under responsibility of AMER (Association of Malaysian Environment-Behaviour Researchers), ABRA (Association of Behavioural Researchers on Asians) and cE-Bs (Centre for Environment-Behaviour Studies), Faculty of Architecture, Planning \& Surveying, Universiti Teknologi MARA, Malaysia.

DOI: https://doi.org/10.21834/ebpj.v5iSI1.2325

\subsection{Introduction}

Malaysia has been recognized as the halal centre to the majority of countries across the globe due to its robust halal standards as well as the enforcement of halal. With this positive development, members of society are becoming more aware in terms of the halal status of the products and its derivatives in each of the supply chain. Because of this, with the adoption of science and technology as well as the availability of mass media and its vehicles are likely to boost the dissemination of the knowledge on halal among the public. Since the divine revelations related to food are widely in general forms, there is a need to resolve the ijtihadic matters, and one of the best methods used is 'urf.

'Urf lexically refers to 'custom'. The root word of 'urf comes from the Arabic word of 'arafa, which means knowing or recognition (AlMunjid, 2001). According to Ibn Manzūur (1997), the word 'urf also denotes a commonly known matter, ma 'rūf, which refers to good deeds. In short, 'urf means something that is known and widely accepted by the people. In terms of its technical meaning, al-Jurjānī (2003); al-Suyūțī (2011); Ibn Nujaym (1993) have defined 'urf as something that has always been practised continuously by the people whereby the practice is accustomed and accepted in ordinary life in the way that they could easily understand the method reasonably.

Moreover, Aznan (2011) further asserted that ' urf is standard in every single life in no particular reason wherein it occurs continuously and is patented naturally. At this point, Taiwo (2013) has concluded that the meaning of 'urf relates to societal values where it could be articulated as tradition. Nevertheless, Mahmood Zuhdi (2011) has advocated that the understanding of the importance of 'urf does not refer to the practice only concerning the general people. Still, it also includes the current facts (haqīqah 'ilmiyyah) that happen during that particular time. In brief, the definitions of 'urf provided by the scholars are almost interrelated and comprehensive, where it is related to the standard practices in the life of society. It does not merely limit to the tradition only, but must also be understood broadly and that includes the current fact existing at that particular time. Thus, this paper seeks to examine the determinant factors of fatwa's decisions on food-related issues resolved by the jurists based on the approach of 'urf (custom).

eISSN: 2398-4287 ( 2020. The Authors. Published for AMER ABRA cE-Bs by e-International Publishing House, Ltd., UK. This is an open access article under the CC BYNC-ND license (http://creativecommons.org/licenses/by-nc-nd/4.0/). Peer-review under responsibility of AMER (Association of Malaysian Environment-Behaviour Researchers), ABRA (Association of Behavioural Researchers on Asians) and cE-Bs (Centre for Environment-Behaviour Studies), Faculty of Architecture, Planning \& Surveying, Universiti Teknologi MARA, Malaysia.

DOI: https://doi.org/10.21834/ebpj.v5iSI1.2325 


\subsection{Literature Review}

Concerning to the rulings related to food, al-Zuhayli (1997) has mentioned that the food-related issues are determined by the Quran, Sunnah, ijmā 'and qiyās. However, when problems arise due to new developments or technological changes, the rulings could be sought through ijtihadic process that includes 'urf (Mohammad Aizat et al., 2011, Mohammad Hashim, 2013). At this point, al-țayyibāt is one of the main essential elements in determining the halal status of food and its derivative products when there is no explicit evidence from the Quran and Sunnah. It is because there are many verses in the Quran, which directly link halal with al-țayyibāt to show that alțayyibāt is a characteristic of halal food. For instance, Allah has mentioned in Surah al-A rāf (7):157 about the attributes of halal of food, "He allows them as lawful for what is good (al-țayyibāt) and prohibits them from what is bad (al-khabā' ith)".

Al-Qurțubī (2005) has explained that al-țayyibāt here contains a praising word which means halal in the Mālikī School's opinion. In contrast, al-khabā' ith is the opposite meaning of halal, which is haram. Nevertheless, the majority of jurists refer to al-țayyibāt as based on the people's perception of good food (Abdul Wahab, 2012). It has shown that the jurists are not in agreement with the meaning of alțayyibāt (sing; țayyib) and al-khabā 'ith (sing; khabith). Therefore, it is imperative to know the halal status of food because consuming haram food will lead to hell (Al-Sharbīnī, 2004). There is a hadith narrated by Jābir (may Allah be pleased with him) on the effect of taking haram food, "The flesh that is nourished with the unlawful will not enter paradise" (Sunan al-Darimi, no. 2776). As a result, the Muslims need to have specific legal rulings on that particular case to avoid falling under this situation in the hereafter.

At this point, who is mustațib (authority to verify al-țayyibāt) to say either the food is țayyib or khabith because there are different (ikhtilāf) interpretations of țayyib and khabïth in determining the status of halal of food. On this occasion, there are several opinions on those particular cases in which 'urf comes into the picture. The majority of classical jurists (jumhür) from H. Hanafī, Shāfi' $\bar{i}$ and Ḥanbalī except for Mālikī and Ibn 'Abbas in view that the criteria of istițābah (taste) of food are left to the 'urf al- 'Arab whereby if the Arab people feel the food is khabīth, therefore it is haram such as insects, frog, crabs and turtles (Al-Buhūti, 1982; Al-Nawāwī, 2000; Ibn Rushd, 1995,). This view is based on what Allah has mentioned in the previous surah al-A rāf, verse 157 (Al-Mawardī, 2003).

In this regard, every person has a different taste as well and might view food from a different perspective. Consequently, it will lead to different understandings and positively will influence the process of ijtihād between one place to another (Abdul Wahab, 2012). In brief, this 'urf could be interpreted as local 'urf whereby the istițābah of food refers to the societal 'urf by all means that the țayyib and khabith could be influenced according to social life. Lastly, modern jurists emphasised that in determining the criteria of istițābah and istikhbāth the experts in that area should be referred. This judgement is actually from the personal opinion of contemporary jurists like Ali Mustafa (2009) and Abdul Wahab (2012) in their manuscript of fiqh al-at imah. According to them, țayyib also refers to what is right and benefits people and does not endanger life, whereas khabith is when it harms life or society. Henceforth, the best way to know whether the food is good or bad is through opinions from the experts of that particular area. As a result, this opinion represents the standard practices that are perceived by the member of the group and considered as 'urf khass (specific 'urf).

In summary, the origin of food is halal unless there is any evidence from the Quran and Sunnah mentioning that the food is haram. Besides, there is no discussion of the status of food in the Quran, Sunnah, ijmā 'and qiyās;' it can be deduced via ijtihād in which 'urf is one of the most suitable sources to clarify the halal status of food.

\subsection{Methodology}

The objective of this study is to examine the determinant factors of fatwa's decisions on food-related issues resolved by the jurists based on the approach of 'urf, and at the same time to verify the possible causes of the adoption of 'urf in the available fatwa decisions issued by Malaysian fatwa institutions. This is an exploratory study and, thus, to get reliable data, document analysis techniques were applied, which involved both primary and secondary types of data. The preliminary data used in this research include the excerpts of the fatwa that were already compiled by JAKIM for the National Fatwa Committee and the fatwa available through the internet for the State Fatwa Committee. Meanwhile, for the secondary data, resources such as books, journal articles, and authoritative articles from the internet were referred to support the arguments. The data were analysed by using content analysis techniques as well as constant comparative techniques in ensuring that it met the objective of the study. This research is confined to the Malaysian 'urf from both the national and state level. Researchers acknowledge the significance of other Muslim countries and classical fatwa to be referred to. However, due to time limitation and inaccessibility, it could not be done.

\subsection{Findings and Discussion}

The results denoted that the decisions of the fatwa influenced by 'urf are categorised into three:

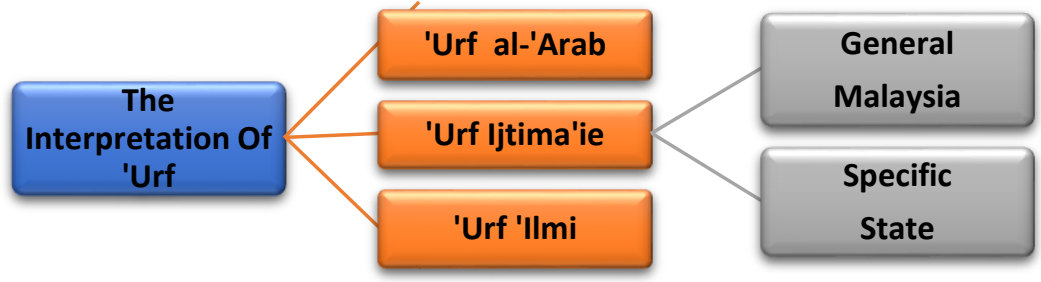

Fig. 1: The Interpretation of 'Urf on Food Related Issues Based on the Fatwa Issuances in Malaysia 


\section{1'Urf al-Arab}

First of all, the 'urf al-Arab becomes an indicator for the scholars in Malaysia to resolve the food-related issues in several fatwas in Malaysia. This is due to Malaysian that perceives Shāfi 'i School of thought as the primary reference in determining Islamic legal ruling (fatwa). As a result, it has influenced the lifestyle of the Muslim society broadly as well as the Islamic legal system (Noor Naemah, 2007). Because of this can be found in the enactments of every state in Malaysia, excluding the state of Perlis. This is due recognition of Shafie school as an official school in each state of Malaysia except Perlis. After this, Part III of the appointment of the mufti, authority in religious matters and the Fatwa Committee of Terengganu, for example, has emphasized that the Fatwa Committee will follow the qawl mu 'tamad from the Hanbalī, Hanafĩ and Mālikī Schools if the qawl mu'tamad of the Shāfi ī School is opposed to the mașlahah of the public. Besides, if there is no reasonable opinion in any of the four schools, the Fatwa Committee shall conduct ijtihād without being bound with any schools' views (The Administration of Islamic Religious Affairs of Terengganu Enactment, Section 54 (1-3), 2001). As a result, the parameter of tayyiban from the Shafi'e school of thought that gives priority to the 'urf of the Arab people particularly relating to the animals either it is pleasing or repulsive, becomes the primary reference for the scholars during the Islamic legal deduction process.

Concerning the issuance of the fatwa from Federal Territories through the medium of Irsyad al-Fatwa $188^{\text {th }}$, on the usage of escargot for producing cosmetics products, for instance, also has been discussed on the legality of eating the escargot. Based on the discussion from the excerpt of the fatwa, the study has identified that the scholars referred to the 'urf al-Arab as to finalise the ruling of eating the escargot is haram. The sighah (provision) of the fatwa related to the discussion is as follows:

"The illah behind the prohibition of the land animal is due to its blood does not flow like escargot, and it is under the category of khabithah animal. Meanwhile, for the animals that are not mentioned in the Quran and Sunnah, the jumhur fuqaha' (hanafiyyah, Shafieyyah and Hanabilah) left it to the 'urf al-Arab. With this, the animal that is considered as tayyib to the Arab society is halal. However, the animal that is khabith to Arab society is haram. Thus, escargot is based on the "urf of the local society."

(Muhammad al-Hanif, 2017)

In conclusion, it cannot be denied that the influence of the 'urf al-Arab among the scholars in deriving rules is very significant and becomes their parameter in justifying the rulings. If the illah behind the prohibition of the land animal such as escargot is due to the impurity of the animal, thus the animal is categorised as khabith, and it is not halal for consumption.

\section{2'Urf litima'ie}

Secondly, the finding has also shown that the 'urf has influenced the scholars in determining the rulings in the form of 'urf ijtima'ie (societal 'urf) whereby the understanding of the 'urf is based on its locality where the 'urf is perceived. As far as it is concerned, the 'urf becomes the important consideration for the sake of preserving the maslahah of the society, as the "urf is already accustomed in the society psychologically and physically (Abu Sunnah, 2004; Al- Zarqa, 1998). About this matter, the fatwa of eating 'balut' that issued by the Federal Territories through the medium of Irsyad al-Fatwa $96^{\text {th }}$, for example, has explained that eating 'balut' is makruh (reprehensible) because the status of the embryo is not considered as an animal that is entirely alive. Concerning this, with the support of Islamic legal maxim, the origin of a matter is permissible unless there is evidence as to show its contrary. Thus, Islam only legalises its permissibility when the thing indeed has reliable evidence, as stated in the hadith of the Prophet PBUH (Umar Mukhtar, 2015). Hence, the consideration of the issuance of the rulings is also supported with the basis of the 'urf of the society as the following:

"... Besides, 'adah and the 'urf of the society in Malaysia do not eat the egg that contains the incomplete embryo of chick and duck as well as it is not hatched yet..."

(Umar Mukhtar, 2015)

Furthermore, another fatwa related to this 'urf is on the naming of the food and drinks: halal status and its issues produced by Bayan Linnas 77th series also stressed on the importance of considering the concept of 'urf in naming food. The significant sighah of the fatwa is as follows:

"In Islam, 'urf or adah of the society is among the important factor in naming food. This is because 'urf is divided into two, i.e. 'urf sahih and 'urf fasid. In reality, 'urf sahih is the action or speech that does not contravene to divine texts, does not eliminating the maslahah as well as preventing from harm. In contrast, urf fasid is the action or speech that is contradicted with divine texts and leads to harm and prevent the maslahah"

(Pejabat Mufti Wilayah Persekutuan, 2016)

Based on the above statement, it shows that the 'urf of the society should adhere as long as it is in line with Shariah principles and its requirement. This is because the rulings deduced by considering the life of the society as portraying Islam respects the things or actions that are already prevalent to them. This simultaneously ensures that the rulings delivered to the society are rational and practical.

Moreover, the determinant factor of food-related rulings through 'urf of the society could also be seen in the fatwa of eating the squid ink in which Mohamad Razif (2016) has discussed that the squid is permissible for consumption as well as its ink and this is based on the verse of the Quran, "To hunt and to eat the fish of the sea is made lawful for you..." (al-Maidah: 96). However, the ruling opposes the existing ruling from the State Fatwa Committee of Terengganu in 2011 on this issue whereby the consumption of squid and its ink is forbidden due to the ink is najs (filth). Indeed, the permissibility of the MAIWP fatwa on this issue is by referring to the nature of the dish is not harmful and the local society has recognised it as the dish. Therefore the maxim of 'Custom is arbitrary' (al-'Adah muhakkamah) becomes a tool to support its permissibility.

Given this matter, 'urf ijtima'ie plays an important role in scholars in the process of determining Islamic legal rulings. According to this, it could be comprehended that the 'urf 'ijtima'ie in Malaysia could be viewed based on its locality where the law is governed based on the authority of a state or issued by National Fatwa Committee. The consideration of the locality within the authoritative place showing that there is an effort to preserve the life of the public society. Therefore, it can avoid fitnah and reduce the level of ignorance in terms of the life of society when issuing the rulings. 


\section{3 'Urf 'IImi}

In line with the prior discussion, the recognition of 'urf in the Islamic legal deduction process in Malaysia could also be seen through several fatwas that intricately related to the development of science and technology. Burke, Bergman and Asimoc (1985) have asserted that society may experience changes on a scale that includes a qualitative change in behaviour and structure due to the impact of science and technology. Thus, it is important to acknowledge the 'urf 'ilmi (scientific 'urf) because the changes of the facts may help the jurists to deduce legal rulings in a more feasibly way in different contexts. As a result of this consideration, the accuracy of fatwa's decision could be preserved to ensure the rulings deduced are practical and reasonable.

A notable example of the meticulously influenced by 'urf 'ilmi is the latest fatwa of horseshoe crab (belangkas) issued by National Fatwa Committee in which the status of the consumption of horseshoe crab has been reviewed and revised to justify its legalities. This is because the Malay society still perceives the animal as their meal. However, the practice of the society contradicts with the fatwa derived from the classical fatwa of Malay manuscripts like al-Banjari (2008) that has stated that it was forbidden to eat horseshoe crab because it was classified under the category of barma'ie animal (live in water and land) and a repulsive animal as well. In contrast, the recent fatwa by the National Fatwa Committee in 2011 that is after the consideration of the opinion from the experts in aquatic animal, opined that the horseshoe crab is an aquatic animal as well as in line with the majority of the scholars in view that aquatic animal is halal for consumption (e-fatwa, 2011a). Consequently, with the aids of science and technology, the previous fatwa has been shifted to halal because the animal is not considered as repulsive and the scientific finding has shown that this animal is not barma'ie animal.

Because of matter, it suits with the related Islamic legal maxim of, 'the evolution of rulings is based on the changing of times and circumstances' (taghayyur al-ahkam bi taghayyuri al-azman wa al-amkan). Therefore, for the ijtihadic matter like this case, considering the changing of the scientific facts about the status of the animals in which previously the maximum knowledge could only categorise the animal into barma'ie animals, Later, it turns to be grouped under the aquatic animals which later is based on the scientific findings from the group of people who studied it, hence, actually is acceptable and in line with the spirit of maqasid al-Shariah.

Furthermore, the sequence of the fatwa on alcohol also could be demonstrated as considering the 'urf 'ilmi as the tool to support the ruling on the particular alcohol-related issues. The study has shown that there is the inconsistency of fatwas exists in those issued in Malaysia from 1984 until 2011. Based on a fatwa issued by National Fatwa Committee, e-Fatwa (1984; 1988), the form of legal rulings on the alcohol in food and drink is in general form, in which there is no determination of percentage during that time. However, the form of the fatwa has evolved in a manner which calls for a specific percentage of allowable alcohol contained in food and drinks.

Initially, the fatwa on alcohol levels issued by the State Fatwa Committee of Johor, e-Fatwa (2010) on the ethanol alcohol used in food has shown that the percentage of permitted alcohol is up to $0.01 \%$ only. After that, the latest fatwa on this issue came out in 2011 from National Fatwa Committee for alcoholic drinks where the level of permitted alcohol must not be more than $1 \% \mathrm{v} / \mathrm{v}$ and for using alcohol for stabilization, is up to $0.5 \%$ for the end product (e-Fatwa, 2011b). Taken together, these results indicate that the increment of the level of percentage is owing to the 'urf of the food industry is taken into account as well as the opinion from the scientific community on the real intoxication levels of the alcohol contains in the food products.

The progressive scientific research in the realm of alcohol one of the determinant factors that lead to the evolution of the fatwa on permitted alcohol in food and drinks. Beginning from no determination of any level to the specific level of permitted alcohol shows that jurists have considered the new knowledge which appeared at that particular time. Indeed, halal food industries conditions and also the development of science and technology ( 'urf 'ilmî) in detecting the level of permitted alcohol are the most important consideration in determining legal rulings in food and drinks. This is due to the cause of alcohol becomes haram is intoxication and not the alcohol itself, which derived from the halal production.

In summary, it has shown from this discussion that the consideration of 'urf 'ilmi is very significant to determine the food-related rulings. As the scientific findings or opinions from the specific people who experts in that particular area like determining the accurate percentage as well as grouping the animal in specific group, thus the rulings deduced to the society is rational and practical to follow since all of these elements is for the sake of preservation of essential values of maqasid al-Shariah.

On this matter, there is a lot of factors that the scholars consider when the 'urf is regarded as an instrument to support the rulings like, the perception of the Arab people of the repulsiveness of animals, the locality where the society life and governed, as well as the development of knowledge that been recognised by the specific people in a particular area. All of these considerations are very significant to the scholars during the process of Islamic legal deduction to assure that the rulings for ijtihadic matters particularly for the food-related issues are accurately disseminated to the society.

\subsection{Conclusion \& Recommendations}

There is a lot of emerging halal food-related issues since the realm of food has been gradually industrialized, and this made the need in resolving the issues is so significant, particularly to the scholars and the rulers. As far as the matters related to food issues in the divine texts revelation are extensively general, the 'urf important roles are to assist the scholars to resolve the issues in the best manner. Concerning this, the process of identifying which 'urf must be made a consideration as either 'urf al-'Arab, 'urf ijima'ie or 'urf 'ilmi. Thus, scholars must have in-depth understanding by conducting intensive research to ensure that the rulings are deducible based on ijtihadic matter relating to 'urf of the Malaysians. It is suggested that the national and state fatwa committee should have collaboration with food-related authoritative bodies in making new fatwa. This is to ensure that the 'urf will always be prioritized in fatwa making process. 


\section{Acknowledgments}

The authors gratefully acknowledge the help of the Institute of Research Management and Innovation IRMI, of Universiti Teknologi MARA (UiTM) in providing the LESTARI fund (Project Number:600-IRMI/DANA 5/3/LESTARI (0005/2016) and to those involved in this research and also those who contribute to the publication of this short article.

\section{References}

Abdul Wahab Abdussalam Thawilah. (2012). Fikih kuliner (Khalifurahman Fath \& Solihin, Trans). Jakarta: Pustaka al-Kauthar

Abu Sunnah, Ahmad Fahmi. (2004). Al- 'Urf wa al- 'ādah fĩ ra 'yu al-fuqahā' . Cairo: Dār Al-Basāi'r.

Al-Banjari, Syeikh Muhammad Arsyad. (2008). Sabil al-muhtadin 2. Surabaya: Pt. Bina Ilmu.

Al-Buhuti, Manșūr Bin Yūnus Bin Idris. (1982). Kashshāf al-qinā’ 'an matn al-iqnā' (Vol.6). Beirut, Lebanon: Dār al-Fikr.

Al-Dārimī al-Samarqandī, 'Abdullah Bin 'Abdul Raḥmān. (2000). Sunan al-Dārimī (Vol.2, p.203). Cairo: Dār al-Hadīth.

Al-Jurjānī, 'Alī Bin Muḥammad. (2003). Al-Ta 'rīfāt (pp.122-123). Beirut: Dār lḥyā’ al-Turāth al- 'Arabī.

Al-Mawardī, Abu Ḥasan ‘Alī Muḥammad. (2003). Al-Ḥawī al-kabīr (Vol.19). Lebanon: Dār al-Fikr.

Al-Munjid fi al-lughah al- 'arabiyyah al-mu 'așirah (2nd ed.). (2001). Beirut, Lebanon: Dar al-Mashraq.

Al-Nawāwī, Zakariyya Muhyiddīn. (2000). Al-Majmu' (Vol.9). Beirut: Dār al-Fikr. Al-Qaradawi, Yusof. (1995). The lawful and the prohibited in Islam. Kuala Lumpur: Islamic Book Trust.

Al-Sharbīnī, Shamsuddīn Muḥammad Bin al-Khāțib. (2004). Mughnī muḥtāj ila ma 'rifah ma 'ānī alfāz al-minhāj (Vol. 4). Beirut, Lebanon: Dār al-Fikr.

Al-Suyūțī, Jalāluddīn ‘Abdul Raḥmān. (1998). Al-Ashbāh wa al-naẓa 'ir (5'th ed., Vol.1). Cairo: Dār al-Salām.

Al-Qurțubī, Muḥammad Bin Aḥmad al-Anșarī. (2005). Al-Jāmi' li aḥkām al-Quran. Beirut: Al-Maktabah al- 'Așrīyyah.

Al-Zarqā, Musțafā. (1998). Al-Madkhal al-fiqhī al- 'āmm. Damascus: Dar al-Qalām.

Al-Zuḥaylī, Wahbah. (1997). Al-Figh al-Islāmī wa adillatuhu (4${ }^{\text {th }}$ ed.). Beirut: Dār al-Fikr.

Ali Mustafa Yakub. (2009). Kriteria halal-haram untuk pangan, obat, dan kosmetika menurut al-Quran dan Hadis. Jakarta: PT. Pustaka Firdaus.

Aznan Hassan. (2011). Shariah Principles in Halal Products. Shariah Laws Reports, 2: 29-51.

Burke, J., Bergman, Jules \& Asimoc, I. (1985). The impact of science on society. Washington: National Aeronautics \& Space Administration, NASA.

e-Fatwa, Portal Rasmi Fatwa Malaysia. (1984, April 12). Alkohol menurut pandangan Islam. Retrieved from www.e-fatwa.gov.my

e-Fatwa, Portal Rasmi Fatwa Malaysia. (1988, November 24). Alkohol sebagai penstabil minuman ringan. Retrieved from www.e-fatwa.gov.my

e-Fatwa, Portal Rasmi Fatwa Malaysia. (2010, June 2010). Etil alkohol dalam makanan. Retrieved from www.e-fatwa.gov.my

e-Fatwa, Portal Rasmi Fatwa Malaysia. (2011a, February 21). Hukum memakan daging/isi belangkas dan telurnya. Retrieved from http://www.e-fatwa.gov.my/fatwakebangsaan/hukum-memakan-dagingisi-belangkas-dan-telurnya

e-Fatwa, Portal Rasmi Fatwa Malaysia. (2011b, July 16). Alkohol dalam makanan, minuman, pewangi dan ubat-ubatan. Retrieved from www.e-fatwa.gov.my

Ibn Manz̦ūr. (1997). Lisān al- 'arab (3d ed.). Lebanon: Dar lḥya' al-Turath al- 'Arabī.

Ibn Nujaym. (1993). Al-Ashbāh wa al-nazāa 'ir. Beirut: Dar al-Kutub al- 'llmiyyah.

Ibn Rushd, Abū Walīd Muḥammad Bin Muḥammad. (1995). Sharh bidāyah mujtahid wa nihāyah al-muqtașid (2nd ed., Vol. 3,). n.p.: Dār al-Salām.

Mahmood Zuhdi Abdul Majid. (2011). Tranformasi fikah semasa. Selangor: PTS Islamika Sdn. Bhd.

Mohammad Aizat Jamaluddin, Mahmood Zuhdi Abdul Majid, Mohd Anuar Ramli, Nor Nadiha, Mohd Zaki, Suhaimi Ab Rahman \& Dzulkifly Mat Hashim. (2011). Realisasi pandangan fuqaha tentang makanan berasaskan nilai saintifik semasa. In Seminar Hukum Islam Semasa vii (pp. 1-15).

Mohammad Hashim Kamali. (2013). The parameters of halal and haram in Shariah and the halal industry. Kuala Lumpur: International Institute of Advanced Islamic Studies (IAIS).

Muhammad al-Hanif. (2017, March 24). Hukum penggunaan siput babi dalam penghasilan produk kosmetik. Retrieved from http://www.muftiwp.gov.my/index.php/msmy/perkhidmatan/irsyad-fatwa

Muhammad Razif. (2016, November 22). Hukum memakan dakwat sotong. Retrieved from http://www.muftiwp.gov.my/index.php/ms-my/perkhidmatan/al-kafili-al-fatawi 
Ruzulan, Z., et.al. / CSSR2017, $4^{\text {th }}$ International Conference on Science \& Social Research The Pines, Malacca, Malaysia, 06 -07 December 2017/ E-BPJ, 5(SI1), Jun 2020 (pp.233-238)

Noor Naemah Abd. Rahman. (2007). Amalan fatwa di Malaysia: Antara keterikatan mazhab dan keperluan tarjih, Jurnal Fiqh, 4, 85-102.

Pejabat Mufti Wilayah Persekutuan. (2016, October 31). Penamaan makanan dan minuman:status halal dan isunya. Retrieved from http://www.muftiwp.gov.my/index.php/ms-my/perkhidmatan/bayan-linnas

Taiwo Moshood Salisu. (2013). 'Urf/ ‘ādah (custom): An ancillary mechanism in Shari'ah. Ilorin Journal of Religious Studies, 3(2), 133-148.

Umar Mukhtar. (2015, December 25). Hukum memakan telur balut. Retrieved from http://www.muftiwp.gov.my/index.php/ms-my/perkhidmatan/irsyad-fatwa/635-irsyadal-fatwa-ke-96-hukum-memakan-balut 